\title{
ИЗ ИСТОРИИ НАИМЕНОВАНИЙ СВИДЕТЕЛЕЙ В РУССКОМ ЯЗЫКЕ
}

\author{
THE NAMES OF WITNESSES IN THE HISTORY \\ OF THE RUSSIAN LANGUAGE
}

\author{
ELENA CHASHCHINA
}

\begin{abstract}
AвSTRACT. The author in this research article analyses the names of witnesses in the period from Ancient Russia to the end of the $17^{\text {th }}$ century. Vocabulary is analysed from the point of view of origin, semantics and sphere of usage. Russkaya Pravda (Rus' Justice), birch bark manuscripts and business documents of the 15-17 centuries were used as research sources.

Keywords: historical lexicology, witnesses, juridical lexicon, Ancient Russia

Elena Chashchina, Uniwersytet im. Adama Mickiewicza w Poznaniu, Poznań - Polska, jelena.c@amu.edu.pl
\end{abstract}

ORCID ID: 0000-0002-0309-9179

Институт свидетелей возникает на ранних этапах формирования правовой системы Древней Руси и начинает занимать важное место в судебном процессе, который был близок к древним формам разрешения конфликта - вооруженному столкновению изначально целых групп, а затем отдельных лиц, именуемый поеднком или полем. Арабский писатель X в. Ибн-Даста говорит о славянах: „На борьбу эту (судебную) родственники обеих тяжущихся сторон приходят вооруженными и становятся: тогда соперники вступают в бой..." [Чельцов-Бебутов 1995: 637]. Отметим, что обе стороны, участвующие в процессе, именовались истиями или сутяжниками, чем подчеркивалось равенство сторон. Судебный процесс начинался с подачи иска представителя одной из сторон, затем происходила встреча в суде, где стороны предъявляли свои претензии друг другу в присутствии судьи. Одним из главных доказательств являлось собственное признание. В случае запирательства и нежелания признаваться суд требовал предоставления свидетелей. Если свидетели подтверждали обвинение, то подозреваемый признавался преступником [Момотов 2003: 358-359]. При отсутствии свидетелей прибегали к высшим силам - роте или ордалиям.

Одним из ранних наименований свидетелей является существительное в форме множественного числа ююдие (ююди), использовавшееся 
в Русской Правде, например, в составе формулы людие вылезут со значением 'выступят свидетели': А зуб выбъют, кровъ у него видят во рте, а людие вылезут, то 12 гривен продажи, а за зуб гривна ${ }^{1}$ [ПРП 1952, 1: 199].

Данная лексема фиксируется также в берестяных грамотах, в частности грамоте № 502: Ать ти Видьло како ти было я Ивана яль постави и пьредъ ююдьми како ти взмолвить [Зализняк 1995: 338]. Особый интерес представляет берестяная грамота № 531, в которой некая Анна обращается к своему брату за помощью в предстоящем судебном процессе и просит его выступить при свидетелях: Om Ане покло ко Климяте. Брате господине, попецалоуи о моемо ороудье Коснятиноу. А ныне извета емоу ююдеми. Здесь используется глагол извета (повелительное наклонение от глагола изветовати 'утверждать, объяснять, объявлять'), а также форма ююдеми 'при свидетелях' [Арциховский, Янин 1978: 131]. В следующей фразе автора также подчеркивается роль свидетелей, которые и должны решить исход дела, так как при наличии свидетелей, подтверждающих ее вину, род может от нее отречься, о чем свидетельствует использование традиционной формулы тобе не сестра, а моужеви не жена. А брат может ее убить ( потети 'убить'), не дожидаясь, когда это сделает ее муж: А боудоу люди на томо, тобе не сестра, а моужеви не жена. Ты же мя и потени, не зеря на Федоpa. В описании обстоятельств дела Анна снова ссылается на свидетелей, при которых ее дочь давала деньги в рост: И даяла моя доции коуны ююдеми с ызветом, а заклада просила. По всей видимости, Анна и ее дочь давали деньги в рост, не свои, а Коснятина, причем, в отсутствие мужа. Анна считает, что она производила все денежные операции по всем правилам (публично, при свидетелях, под залог), но Коснятин в чем-то обвинил ее, а также ее дочь и зятя. Вернувшийся муж, узнав об этом, выгнал Анну из дома и хотел убить [Арциховский, Янин 1978: 131-133]. В этом документе мы видим многочисленные ссылки на лиц, именуемых люди, которые могут дать показания по существу дела. Данная семантика реализовывалась также в словосочетании люди добрые: А на то люди добрые Иван меншей Петра Козмина сынб, Левонтеи Митюнин, Максим Михайлов [СлРЯ XI-XVII вв. 1981, 8: 342].

В Русской Правде для наименования свидетелей использовались два термина видок и послух, причем нередко в аналогичных контекстах, например, в статьях второй и тридцатой: Или будеть кровав или синь надбражен, то не искати ему видока человеку тому...; Аще же приидеть кровав мужь любо синь, то не искати ему послуха [ПРП 1: 77, 79]. Здесь мы сталкиваемся с проблемой, которая до сих пор во многом остается дискуссионной: в чем заключается различие этих двух лексем? Взгляд на видока

\footnotetext{
${ }^{1}$ Примеры из источников даются в упрощенной орфографии.
} 
как свидетеля, который видел совершенное противоправное действие (видок от видеть), как правило, не вызывает сомнений. Однако трактовка послуха как свидетеля, который что-то слышал [Дьяченко 1899: 461] и, соответственно, попытка связать данное существительное с глаголом слышать [Фасмер 1987, III: 340] не встречает всеобщей поддержки. Возникает закономерный вопрос: могли ли в суде в качестве доказательства приниматься показания на основе слухов? Положительный ответ на этот вопрос многим исследователям представляется весьма сомнительным. В частности, Максим Исаев утверждает, что

подобное толкование невозможно, во-первых, потому что объективные данные права... этому противоречат; во-вторых, юридическая природа свидетельствования по слуху ничтожна во всех правовых системах древности и современности - это лжесвидетельствование [Исаев 2001: 80].

В этой связи можем обратиться к источникам, в частности к одной из берестяных грамот (грамоте № 154), которая представляет собой протокол судебного заседания начала XIV века. Грамота начинается с вопроса судебных следователей, обращенного к свидетелю по вопросу тяжбы, а именно рассчитался ли Филипп с Иваном Стойком: Bоспросиле правищике Оманта ростягале сь Фипе с БІваномь Стоикомб. Омант, выступающий в качестве свидетеля, заявляет: Виделе есмь и июле промежи Филипомь Иваномъ. Дале Филипе Стоику 3 рубле серебромъ и 7 гривенъ кунь и конь. В данном тексте фиксируется формула, которая произносилась свидетелем виделе есмь и иуюле 'я видел и слышал' [Жуковская 1959: 54]. По поводу этого судебного заседания Лев Черепнин поясняет, что речь идет о разборе дела, случившегося в праздник, вероятно, во время какого-то торжественного собрания или пиршества, где-то за городом, на погосте или на торгу. В результате выяснилось, что Иван Стойко ограблен Филиппом, который должен вернуть ему 3 рубля серебром, 7 гривен кун и коня. Разбор подобных дел согласно Псковской судной грамоте производился при помощи послуха [Черепнин 1969: 349-350]. Таким образом, на судебном процессе Омант, выступая в качестве послуха, говорит: „Я видел и слышал".

Некоторые исследователи, у которых вызывает сомнение связь термина послух с глаголом слышать, обращаются к тому обстоятельству, что истец в судебном процессе ссылается на показания свидетеля (послуха) и использует при этом глагол илюся - форму первого лица от глагола слатися, значение которого определяется как 'ссылаться на кого-либо, что-либо с целью доказать свою правоту'. Об этом писал еще Николай Дювернуа: „...наши послухи стали так называться потому, что на них слались стороны (шлюсь, слатися, посылатися, послух)" [Дювернуа 1869: 
102]. Данную точку зрения отстаивает историк права Исаев и с горечью отмечает:

Дело в том, что при толковании этого слова сталкиваются данные двух наук: исторической лингвистики и истории права. Лингвист обязательно укажет, что слово послоухъ произошло от слоухъ, тот, в свою очередь, от слышати, но никак от корня -сыл-; -съл-, тогда бы непременно было бы посълоухъ [Исаев 2001: 79-80].

Формула шлюся на (кого) являлась традиционной, о чем свидетельствуют берестяные грамоты. В частности, в одной из них читаем: на том ся шию отняли оу мене Селиванке да Михеике... конь в три рубле седло в полтину вотола в полтора... [Зализняк 1995: 541]. Эта формула просуществовала до конца XVII в., находим ее в правых грамотах, которые содержали описание судебного процесса. В грамоте, содержащей протокол суда князя Петра Великого о спорном луге Антоньева монастыря с крестьянами, говорится:

И князь Петр вспросил попа Федора да старцов Ионы да Васьяна: кому ж то у вас ведомо, что тот луг ваш монастырской изстарины? И поп Федор да старци Иона да Васьян так ркли: ведомо, господине, то у нас их же христианом волостным... Ивашку Фомину, да Дениску Якутину..., на тех ся, господине, и шлем. И князь Петр вспросил Тараска: а ты на Иванка на Фомина, да на Дениска... шлешь ли ся? И Тараско... так рек: шлюсь, господине. И послались обои истци [АФЗХ 1951, 1: 127].

По материалам источников глагол слатися использовался в составе словосочетаний слатися (послатися) въ видъ (въ видение), слатися въ слухъ, въ ведомо, слатися въ послушество. Слатися въ видъ (въ видение) означало 'ссылаться на виденное очевидцами': А будет ищея или ответчик хотя на одного человека пошлетияа из виноватого в слух или в виде, и тое его правды спросити: что скажет, так и вершит без целованья [СлРЯ XI-XVII вв. 1975, 2: 171].

Слатися въ слухъ, въ ведомо - 'ссылаться на свидетелей, слышавших что-либо, ссылаться на то, что всем известно': И ищея или ответчик илютие на иных b слух и на иных в видение и в ведомо, а проти в тово истеи или ответчик шлютие $b$ послушество [СлРЯ XI-XVII вв. 1975, 2: 173]. Лексема послушество фиксируется в книжных текстах церковного характеpa XI в. со значением 'то, что служит подтверждением, удостоверением какого-либо факта, события; доказательство'. Например, в Изборнике Святослава 1073 г. читаем: Правъдьнааго от погыбаюштиихъ нечьстьникъ избави, бежавъша сънесения очию пяти градъ, его же и доныня послушьство греху курить ся земя. Второе значение данного существительного - 'свидетельство, свидетельское показание' - также отмечается в текстах указанного 
периода: Послущьствомь единого клеветьника [СлРЯ XI-XVII вв. 1991, 17: 191-192].

Глагол послушествовати отмечен в церковной литературе со следующими значениями: 1) 'подтверждать, удостоверять что-либо в качестве очевидца или осведомленного, знающего лица; доказывать': Азъ на се родихъ ся и на се придохъ въ миръ, да послушъствую о истине; 2) 'открыто объявлять, заявлять при свидетелях': Послушьствую предь гмь и предъ избьраными его англы; 3) 'свидетельствовать, давать свидетельские показания': Глагола ему Пилать: Не слышиши ли колико на тя послушьствують [СлРЯ ХI-XVII вв. 1991, 17: 192]. Можно также принять во внимание семантическую синкретичность однокоренного слова послушание, в котором отмечены следующие значения: 'слушанье, слышанье', 'слух, молва', ‘послушание, повиновение', 'подчинение', 'свидетельство', ‘выполнение (служебного) поручения' [СлРЯ XI-XVII вв. 1991, 17: 189-190]. Особенно важны значения 'слышанье, слух' и 'свидетельство', которые могут актуализироваться в термине послух.

Следует обратить внимание еще на одну традиционную черту судебного процесса Древней Руси: каждая из сторон являлась на судебное заседание со своими родственниками, соседями, которые активно вмешивались в процесс, шумно поддерживали своего истца, нередко криками, тем самым парализуя работу суда. Как отмечает историк права Виктор Момотов, княжеские суды и суды феодала, которые активно начали проводиться с X-XI вв., сталкивались с этим явлением и пытались с ним бороться [Момотов 2003: 341-342]. Присутствовавшая с каждой стороны группа людей не просто давала показания по существу дела, но также подтверждала репутацию своего истца, то есть свидетельствовала о его „доброй славе” и доказывала, что он не мог совершить противоправное действие. Здесь мы можем вспомнить повальный обыск, который представлял собой опрос представителей общины, включавший главный вопрос: ıихой ли тот человек или добрый? По мнению некоторых исследователей, такую же роль на суде выполнял послух, выступая не просто в качестве очевидца происшедшего, но и в роли защитника интересов того лица, чью сторону он представлял [Черепнин 1969: 348]. Кроме того, послухи могли принимать участие в поединках вместо истца. Послух брал на себя также и финансовую ответственность: если показания, которые он подтверждал, оказывались ложными, то он должен был участвовать в уплате судебного штрафа или пени [Исаев 2001: 79].

В качестве наименования свидетеля фиксируется существительное слух: А на то слуси: Левонъ ключникъ, да Левонтей Федоровъ; А дали есмя имъ на техъ земляхъ сорокъ рублевъ... а на то слуси... [СлРЯ ХI-XVII вв. 2000, 25: 140]. Из берестяных грамот мы узнаем, что сами свидетельские по- 
казания именовались термином ухо. В грамоте № 25 читаем: yхо к тобе с Васильемг со Желутковымь и ты ухо положи на суде а на мене се шли на томь итоо еси конь позналь у немиина и ухо еси за мене дале и немицне с себе поводъ сложиле а Веглесе на Вигуя... В документе говорится о том, что его автор выступал на суде в качестве свидетеля, но судебный процесс не был завершен. При его возобновлении автор не смог в нем участвовать, а уполномочил выступить на суде своего адресата, передав показания yхо - с Василием Желудковым. Кроме того, автор указывает: „А на меня ссылайся в том, что ты опознал коня у немца и дал за меня свидетельское показание, а немец от себя обвинение отвел, а обвинил Вигуя" [Зализняк 1995: 537]. В данном фрагменте используются словосочетания дати ухо, положити ухо со значением 'дать свидетельские показания'. Артемий Арциховский, подтверждая данную семантику, отмечает:

При моем докладе о новгородских раскопках в Институте языкознания Академии Наук академик В.В. Виноградов поддержал это мое предположение, указав, что в петровское время существовал термин ушник, что значило 'судебный свидетель' [Арциховский 1954: 28].

Содержание грамоты становится более ясным, если мы примем во внимание тот факт, что неявка послуха в суд влекла проигрыш тяжбы [Чельцов-Бебутов 1995: 642]. Таким образом, мы можем сделать вывод, что свидетель слух (nocлyx) являлся в суд и давал или клал ухо. Если же свидетелей того или иного события не было, то обращались к главному свидетелю людской земной жизни - к Богу, что подтверждается следующими словосочетаниями: Богъ мъжи нама послоухо быль (Грамота № 675) [Янин, Зализняк 1993: 62]; а на то Бог послух (Грамота № 520) [Арциховский, Янин 1978: 115].

Роль послухов была особо важной при совершении той или иной сделки, так как договоры часто заключались устно и именовались смолвою вплоть до первой половины XVII века, когда был издан царский указ об обязательной письменной форме актов [Владимирский-Буданов 2005: 687-688]. Именно послухи фиксировали факт заключения сделки, являлись хранителями информации о ней и привлекались в качестве свидетелей в случае необходимости. В делах, касающихся земельных споров, ссылались на старожильцев и знахарей, которые владели информацией за довольно длительный период. По данным статьи 151 Судебника 1589 г. старожильцы - хто знает межу или преж сего ту землю пахивал и живал [Судебник изаря Феодора Иоанновича 1589 г. 1900: 40]. Юрий Алексеев приводит показания „людей великого князя старожильцев, помнящих за 50 и 70 лет" [Алексеев 1966: 16]. В правой грамоте суда князя Петра Великого о спорном луге Антоньева монастыря с крестьянами Аргуновской 
волости конца XV века говорится: яз, господине, Ивашко Фомин помню за шесдесят лет, а яз, господине, Дениско помню за сорок лет, а яз, господине, Ивашко внук помню за тридијать иет, что, господине, тот иуг... Антониева монастыря изстарины, а не волостной [АФЗХ 1951, 1: 127].

Одно из значений существительного знахарь (знахорь) - 'тот, кто выступает в качестве свидетеля при земельных спорах” [СлРЯ XI-XVII вв. 1979, 6: 52]. Лексема фиксируется в правой грамоте великого князя Ивана Васильевича на спорные земли:

И Ларивоник с товарищи тако ркли: коли, господине, поп наших послухов называет с нами одины истци, ино, господине, у нас знахори на ту землю люди добрые, дворской звенигородцкой старой Ларион Слинков, да дворской нынешней Ермола, да Федот Стряпко... И судьи вспросили обоих знахорев, и Серапионовых и Ларивонковых, с товарищи: скажите вы нам, чья то земля та пустош? ...И Ларивонковы, да Семенковы, да Олешковы знахори Ермак, да Ларивоник, да Стряпко так ркли: то, господине, земля Харина Лагирева... а ту, господине, землю пахал, а холоп был княжь Юрьев Дмитриевичя, а за ним, господине, была роба княгинина Настасьина Коверница [АФЗХ 1951, 1: 98].

Также в правой грамоте 1495 г. о тяжбе попа Григория с Родюкой и Нестериком читаем:

И судья спросил Родюки да Нестерика: А вы шлете ли ся на поповы знахори... И Родюка и Нестерик тако ркли: Шлемся, господине... И судья спросил попа Григорья: А ты шлешь ли ся на Родюкины да на Нестериковы знахори? И поп Григорей тако рекл: Шлюся, господине. И послалися оба исца на обои знахори. И праведчик обоих исцев и обоих знахорей перед судьею поставил [Янин, Зализняк, Гиппиус 2015: 29].

Для обозначения свидетельства знахарей употреблялось существительное знахарство (знахорство): И судья въспросил знахореи стариооых - Богдана Микулина да Тимана: скажыте, брате, как право перед Богомъ, что выше знахорьство, чья то земля, на которой стоим [СлРЯ XI-XVII вв. 1979, 6: 52].

Свидетельские показания старожилов именовались старожиловыми сказками:

Староста Моисеи... велил межу утвердить... по старожиловым скаскам по священникову и по понятых людей приговору; Церковную землю и сенные покосы черезъ указъ и черезъ писцовую книгу отняли и черезъ мирские старожиловые скаски ложнымъ своимъ челобитьемъ [СлРЯ XI-XVII вв. 2008, 28: 10].

Таким образом, участие старожильцее и знахарей в судебном процессе было крайне важным, так как их показания являлись определяющими при вынесении судебных решений. 
Присутствие свидетелей было необходимо ири. оформлении письменного акта, такого рода лица последовательно именовались послухами. Ставя свою подпись на документе, они традиционно, указывая на свой статус, употребляли существительное послух и использовали формулу руку приложить в форме 1-го или 3-го лица. В разъезжей грамоте на митрополичьи земли Переяславского уезда 1519 года значится: B сей розбежжой яз Шарап Семенов сын послух и руку свою приложил. К сей розбежжей грамоте яз Фуник послух и руку приложил [АФЗХ 1951, 1: 122]. Купчая грамота боярина Русина Фомина на деревню Старое Елсуфьево 1526 года заканчивается записью: В сей купчей яз Грибуша послух руку приложил. В сей купчей Олеша послух руку приложил. В сей купчей Иван Матфеев послух руку приложил [АФЗХ 1951, 1: 70]. В одном из документов фиксируется употребление существительного послух в форме предложного падежа множественного числа: В послусех Персилко Михайлов сын и руку приложил [ГААО: ф. 57, оп. 2, т. 1, № 18].

Если обратиться к существительному свидетель в современном русском языке, то оно восходит к старославянскому съведетель со значением 'свидетель, очевидец' [СС 1994: 643]. В источниках фиксируется лексема съведокъ с тем же значением: Иже недугъмь страха одьржимъ... помаза все тело масльмь, и у гроба мало приседе въ лютаго недуга изменися... и мнози симъ съведоци; также со значением 'тот, кто присутствует при удостоверении правильности или подлинности чего-либо': А на то съедоци: панъ Мартинъ воевода [СлРЯ XI-XVII вв. 1996, 23: 105]. Данные существительные изначально связаны со старославянским глаголом ведети 'знать'. Однако встречается и вариант свидетель 'тот, кто является непосредственным наблюдателем чего-либо, очевидец, свидетель (в том числе, свидетель на суде)': Буду свидетель скоро на противныа... и на кленущаася именемъ моимъ [СлРЯ XI-XVII вв. 1996, 23: 159]. Слово свидетель образовано, соответственно, от глагола съвидети 'видеть' [СлРЯ XI-XVII вв. 1996, 23: 161]. Каковы причины трансформации сведетель - сbидетель, и к какому глаголу все же восходит данный юридический термин Видеть или знать, остается до конца не ясным. Фонетический вариант с рефлексом древнего ять в сильной позиции реализуется в лексеме сbидитель, а также глаголе сbидительствовати, зафиксированных в Словаре русского языка XI-XVII вb.: О них же Мофедии епископъ Паторомьскыи, свидительствуеть, яко сии суть вышли ис пустыня Етривьскыя [СлРЯ XI-XVII вв. 1996, 23: 159-160].

Таким образом, существительное сbидетель восходит к лексике старославянской, как и термины послухъ, послушество, послуществовати, которые активно использовались в XI веке в книжной литературе, а затем с теми же значениями перешли в сферу древнерусского права и просу- 
ществовали в ней до конца XVII века. Остается дискуссионным вопрос, почему термины видок и послух параллельно использовались в правовой системе вплоть до XVII в., в чем заключалось их различие? Происхождение и семантика лексемы послух вызывают многочисленные споры и среди историков права, и среди лингвистов. К наименованиям свидетелей относятся также лексемы ююдие (ююди), старожилец и знахарь (знахорь). Показания свидетелей (их свидетельства) именовались терминами ухо, знахарство, а также словосочетанием старожиловые сказки. В заключение заметим, что данная тема представляется интересной, во многих случаях не содержит окончательных ответов и требует дальнейшего исследования, привлечения новых источников.

\section{Библиография}

Алексеев Ю. Г. 1966. Аграрная и сочиальная история Северо-Восточной Руси XV-XVI вв. Переяславский уезд, Москва: Наука.

Арциховский А. В. 1954. Новгородские грамоты на бересте из раскопок 1952 года, Москва: Наука.

Арциховский А. В., Янин В. Л. 1978. Новгородские грамоты на бересте из раскопок 1962 1976 годов, Москва: Наука.

Владимирский-Буданов М. Ф. 2005. Обзор истории русского права, Москва: Территория будущего.

Дьяченко Г. 1900. Полный изерковнославянский словарь, Москва: Тип. Вильде.

Дювернуа Н. 1869. Источники права и суд в древней России, Москва: Университетская типография (Катков и Ко).

Жуковская Л. П. 1959. Новгородские берестяные грамоты, Москва: Государственное учебно-педагогическое издательство.

Зализняк А. А. 1995. Древненовгородский диалект, Москва: Языки русской культуры.

Исаев М. А. 2001. Толковый словарь древнерусских юридических терминов: От договоров с Византией до уставных грамот Московского государства, Москва: Спарк.

Момотов В. В. 2003. Формирование русского средневекового права в IX-XIV вb., Москва: Зерцало.

Судебник изаря Феодора Иоанновича 1589 г. 1900, Москва: Типография Г. Лисснера и А. Гешеля.

Фасмер М. 1987. Этимологический словарь русского языка: b 4-х томах, т. III, Москва: Прогресс.

Чельцов-Бебутов М. А. 1995. Курс уголовно-проиессуального права, Санкт-Петербург: Равена, Альфа.

Черепнин Л. В. 1969. Новгородские берестяные грамоты как исторический источник, Москва: Наука.

Янин В. Л., Зализняк А. А. 1993. Новгородские грамоты на бересте из раскопок 1984-1989 годо6, Москва: Наука.

Янин В. Л., Зализняк А. А., Гиппиус А. А. 2015. Новгородские грамоты на бересте из раскопок 2001-2014 годоһ, Москва: Языки славянской культуры. 
Список сокращений

АФЗХ - Черепнин Л. В. (сост.) 1951. Акты феодального землевладения и хозяйства XIV-XVI веков, ч. 1, Москва: Издательство АН СССР.

ГААО - Государственный архив Архангельской области.

ПРП - Юшков С. В. (ред.) 1952. Памятники русского права, вып. 1, Москва: Государственное издательство юридической литературы.

СлРЯ XI-XVII вв. - Словарь русского языка XI-XVII вb. 1975-2008, вып. 2-28, Москва: Наука.

СС - Цейтлин Р.М. (ред.) 1994. Старославянский словарь (по рукописям X-ХI веков), Москва: Русский язык. 